\title{
Aplikasi Pelayanan Prins Pet Shop Berbasis Android
}

\author{
Agung Nugroho*1, Paryanta ${ }^{2}$, Hartati Dyah W ${ }^{3}$, Wahyuningsih Ayu Safitri ${ }^{4}$ \\ 1,2Program Studi Teknik Komputer, STMIK AUB, Surakarta, Indonesia \\ ${ }^{3,4}$ Program Studi Sistem Informasi, STMIK AUB, Surakarta, Indonesia \\ e-mail: *1agung_new@stmik-aub.ac.id, ${ }^{2}$ paryanta@stmik-aub.ac.id, ${ }^{3}$ hartati.dyah@stmik- \\ aub.ac.id, ${ }^{4}$ wahyuningsihayusafitri@gmail.com
}

\begin{abstract}
Abstrak
Prins Pet Shop merupakan salah satu toko hewan yang menyediakan berbagai produk kebutuhan dan layanan perawatan hewan. Produk kebutuhan yang ditawarkan berupa makanan dan aksesoris hewan, sedangkan layanan perawatan yang ditawarkan seperti, mandi kutu, mandi jamur, styling bulu, potong kuku, penguraian bulu kusut dan pembersihan telinga hewan. Masalah pada toko Prins Pet Shop meliputi, masalah sistem pemesanan layanan perawatan masih manual yang mengharuskan pelanggan datang langsung ke toko untuk memesan tempat perawatan serta masalah pelayanan belum bisa maksimal. Oleh karena itu, dibangunlah layanan baru berupa layanan perawatan home care. Tujuan dari penelitian ini adalah membangun sistem yang memudahkan pelanggan untuk memesan pelayanan dan produk hewan secara online, dimanapun dan kapanpun serta untuk meningkatkan pelayanan terhadap pelanggan. Sistem dibangun dengan menggunakan software Visual Studio Code, bahasa pemrograman Java Script, HTML, CSS, PHP dan MySQL sebagai pengolah database-nya dengan menggunakan Black Box Testing untuk metode pengujiannya. Hasil dari penelitian ini berupa Aplikasi Pelayanan Prins Pet Shop Berbasis Android yang memudahkan pelanggan melakukan pemesanan tanpa harus datang langsung ke toko dan dapat membantu karyawan di Prins Pet Shop dalam melakukan proses pengolahan data produk, data layanan perawatan grooming guna mempercepat pekerjaan serta meningkatkan pelayanan kepada pelanggan.
\end{abstract}

Kata kunci-Android, Perawatan, Toko Hewan, Perawatan Ke Rumah

Abstract
Prins Pet Shop is a pet shop that provides a variety of animal care products and services. The products offered are in the form of animal food and accessories, while the care services offered include flea baths, mushroom baths, hair styling, nail trimming, detangling, and cleaning animal ears. Problems at the Prins Pet Shop store include, the problem of the maintenance service ordering system is still manual which requires customers come directly to the store and order a place of care, also service problems cannot be maximized. Therefore, a new service was built in the form of home care services. The purpose of this research is to build a system that makes it easy for customers to order animal services and products online, wherever and whenever, and to improve customer service. The system was built using Visual Studio Code software, programming language JavaScript, HTML, CSS, PHP, and MYSQL as the database processor using Black Box Testing for the testing method. The results of this study are an Android-based Prins Pet Shop Service Application that makes it easy for customers to place orders without having to come directly to the store and can help employees at Prins Pet Shop in processing product data, grooming care service data to speed up work and improve service to customers. 
Keywords- Hydroponics, Arduino Uno R3, Ph Sensor, EC Sensor, ESP8266, IoT, Nutrition Solution

\section{PENDAHULUAN}

Era globalisasi seperti sekarang ini menjadikan segala hal lebih maju, dengan adanya perkembangan teknologi yang semakin canggih. Sehingga membuat setiap individu tidak merasa asing lagi dengan perkembangan internet. Hal tersebut memberikan peluang yang sangat besar bagi para individu untuk menciptakan sebuah bisnis online. Perkembangan bisnis online memanglah terhitung sangat pesat dizaman yang canggih seperti saat ini, terutama masyarakat Indonesia. Semakin banyaknya masyarakat di Indonesia yang melakukan pembelanjaan untuk kebutuhan sehari-hari, dengan menggunakan sistem online yang sangat mudah dilakukan dari mana saja dan kapan saja.

Pet shop merupakan salah satu bisnis toko yang berfokus sebagai penyedia perlengkapan kebutuhan hewan peliharaan dan jasa pelayanan perawatan, seperti penitipan hewan dan perawatan hewan.

Prins Pet Shop merupakan kategori bisnis pet shop yang beralamatkan di jalan Adi Sumarmo No.169, Kelurahan Ngabeyan, Kabupaten Sukoharjo, Jawa Tengah. Dalam bisnisnya Prins Pet Shop menjual berbagai kebutuhan hewan peliharaan mulai dari makanan hewan dan juga perlengkapan aksesoris hewan termasuk kandang.

Selain menjual berbagai pelengkapan hewan, Prins Pet Shop juga menawarkan pelayanan jasa grooming yang dikhususkan untuk kucing, anjing, marmut, hamster, dan kelinci saja. Ada berbagai macam perawatan hewan di Prins Pet Shop seperti, mandi kutu, mandi jamur, potong kuku, styling bulu, penguraian bulu kusut dan juga pembersihan telinga hewan.

Usaha Prins Pet Shop saat ini mengalami kesulitan dalam pengembangan sistem penjualannya. Adapun permasalahan yang saat ini dihadapi, antara lain: seperti masalah sistem pemesanan layanan grooming masih manual yang mengharuskan pelanggan harus datang langsung ke toko untuk memesan tempat grooming dan juga pelayanan yang belum bisa maksimal sehingga membuat pelanggan yang sudah memesan tempat grooming hewan harus menunggu antrian cukup panjang terlebih dahulu. Berdasarkan permasalahan yang ada, pemilik Prins Pet Shop mengemukakan ide untuk menambah pelayanan baru berupa layanan home care untuk hewan peliharaan.

Melihat hal tersebut, penulis bermaksud untuk merancang dan membangun aplikasi pelayanan pelanggan berbasis android. Dengan harapan dapat mempermudah pelanggan untuk melakukan pemesanan pelayanan secara online dan membantu pemilik toko untuk meningkatkan pelayanan kepada pelanggan. Untuk itu penulis mengangkatnya menjadi materi skripsi dengan berjudul "Aplikasi Pelayanan Prins Pet Shop Berbasis Android".

\section{METODE PENELITIAN}

\subsection{Metode Observasi}

Observasi peneliti terlibat dengan kegiatan sehari-hari orang yang sedang diamati atau yang digunakan sebagai sumber data penelitian [12]. Peneliti langsung mendatangi Prins Pet Shop untuk memperoleh data yang berhubungan dengan data-data informasi kemudian kejadian ini dicatat dan didokumentasikan.

\subsection{Metode Wawancara}

Wawancara digunakan sebagai teknik pengumpulan data apabila peneliti ingin melakukan studi pendahuluan untuk menemukan permasalahan yang harus diteliti, tetapi juga apabila peneliti ingin mengetahui hal-hal dari responden yang lebih mendalam [12]. Wawancara dilakukan dengan cara mengadakan tanya jawab kepada owner dari Prins Pet Shop yang berkaitan dengan penelitian yang dilakukan. 


\subsection{Metode Pustaka}

Metode pustaka merupakan teknik pengumpulan data dengan mengadakan studi penelaah terhadap buku-buku, literatur-literatur, catatan-catatan, dan laporan-laporan yang ada hubungannya dengan masalah yang dipecahkan [11].

Penulis membaca atau mempelajari buku-buku referensi literature yang berhubungan dengan masalah yang akan dibahas guna memperoleh landasan teori untuk keperluan menganalisis data.

\subsection{Analisis Sistem}

Untuk menganalisa kelemahan sistem diperlukan langkah untuk mengidentifikasi dan memberikan solusi terhadap kelemahan sistem yang ada, maka sebagai landasan penulis menggunakan metode atau kerangka PIECES yang terdiri dari performance, information, economy, control, efficiency dan service.

Analisis ini digunakan sebagai alat ukur untuk menentukan sistem baru layak atau tidak karena enam aspek ini harus mengalami peningkatan ukuran yang lebih baik dari sistem lama agar dapat mendukung dalam kelancaran proses admin.

a. Performance (Analisa Kinerja Sistem)

Pelayanan yang kurang efisien karena untuk mendapatkan layanan perawatan hewan, pelanggan diharuskan mengantri terlebih dahulu. Selain itu, saat pelanggan ingin membeli produk kebutuhan untuk hewan peliharaannya, pelanggan harus datang langsung ke toko.

b. information (Analisa Informasi)

Informasi mengenai antrian pelayanan perawatan harus selalu di update supaya tidak salah memberikan informasi antrian kepada pelanggan.

c. Economy (Analisis Ekonomi)

Biaya yang tinggi untuk memasang iklan dimedia cetak, elektronik dan pencetakan brosur.

d. Control (Analisis Pengendalian)

Keterlambatan mangakses data yang disebabkan oleh penumpukan arsip sehingga mempersulit mencari data yang dibutuhkan.

e. Efficiency (Analisis Efisiensi)

Dalam pengerjaan pesanan pelayanan perawatan grooming dan atau produk kebutuhan hewan serta metode yang pembayaran masih menggunakan nota kertas yang rentan dengan rusak dan hilang.

f. Service (Analisis Pelayanan)

Pelayanan terbatas yang belum dapat memberikan kesan pesanan yang mudah dan cepat bagi pelanggan baru maupun pelanggan lama. 


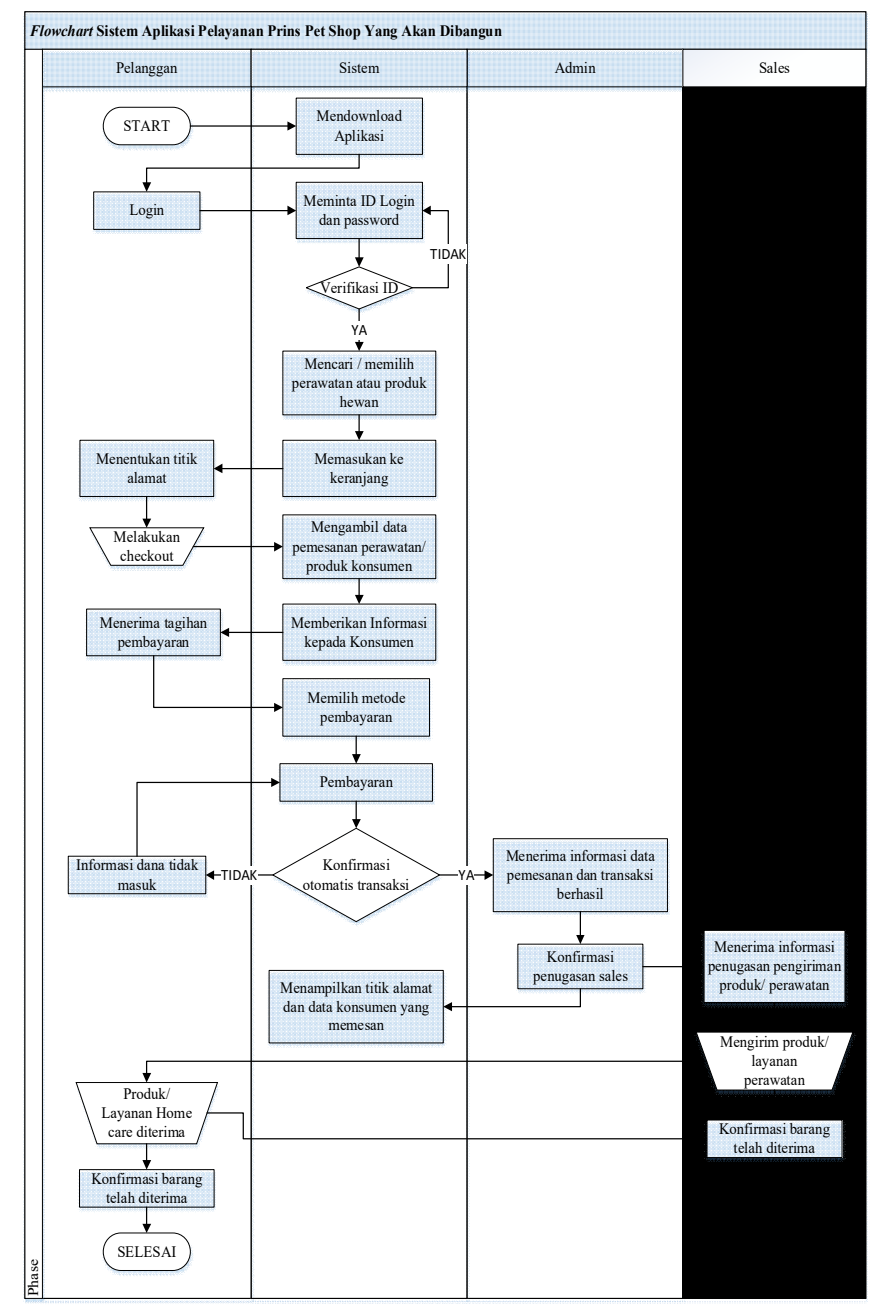

Gambar 1. Flowchart Sistem

Usecase adalah abstraksi dari interaksi antara sistem dan aktor. Dalam Aplikasi Pelayanan Prins Pet Shop Berbasis Android akan dibahas dalam usecase yaitu mengenai aksi antara aktor yang meliputi admin, sales dan pembeli.

a. Admin adalah aktor yang mengelola data produk, data perawatan home care, data pemesanan, data karyawan dan mengkonfirmasi penugasan sales dari web admin.

b. Sales adalah aktor yang melakukan pengiriman produk atau perawatan home care dan mengkonfirmasi barang telah diterima oleh pelanggan dari web admin.

c. Pelanggan adalah aktor yang melakukan proses pemesanan produk dan perawatan home care melalui aplikasi. 


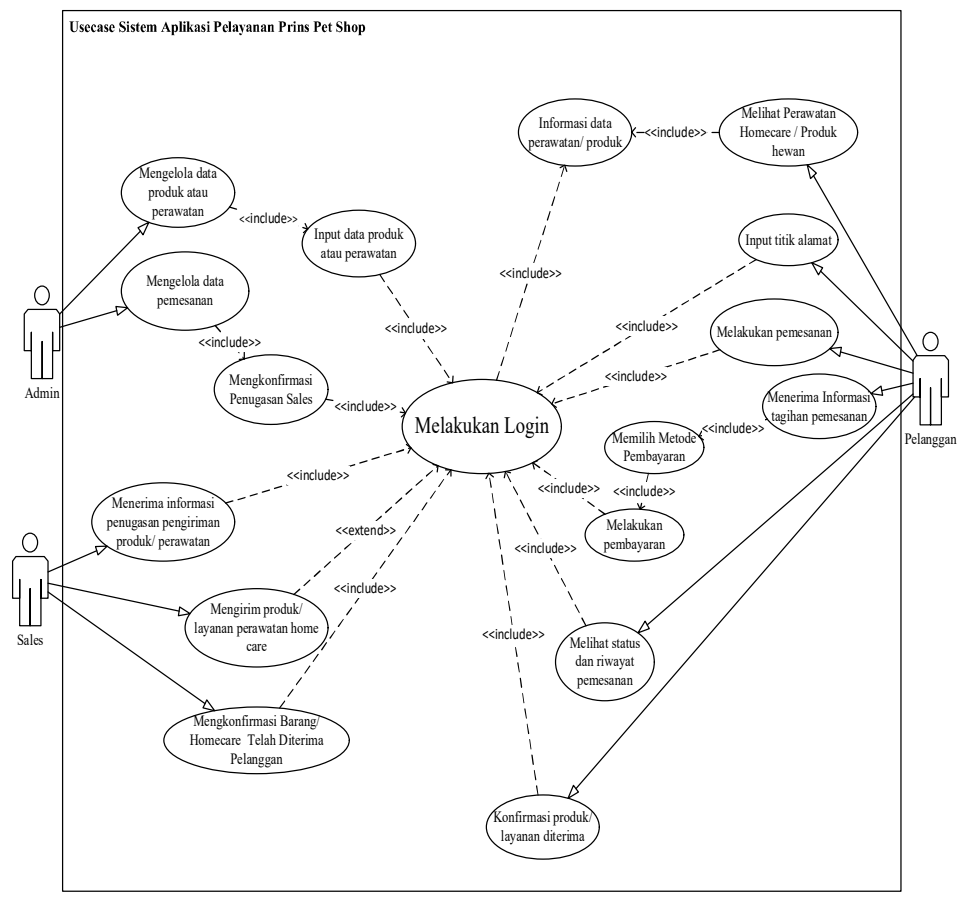

Gambar 2. UseCase Diagram

3. HASIL DAN PEMBAHASAN

\subsection{Tampilan Implementasi Program}

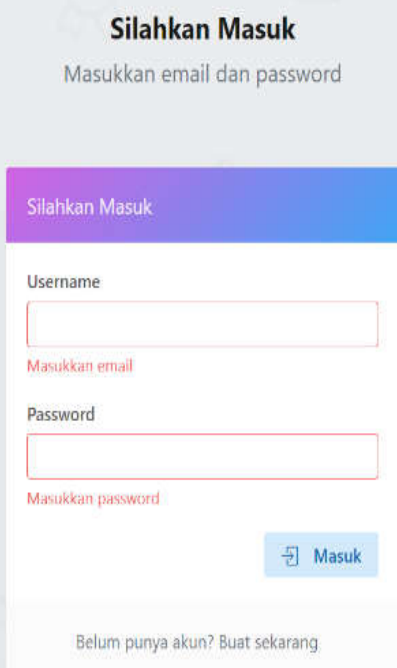

Gambar 3. Halaman Login admin 


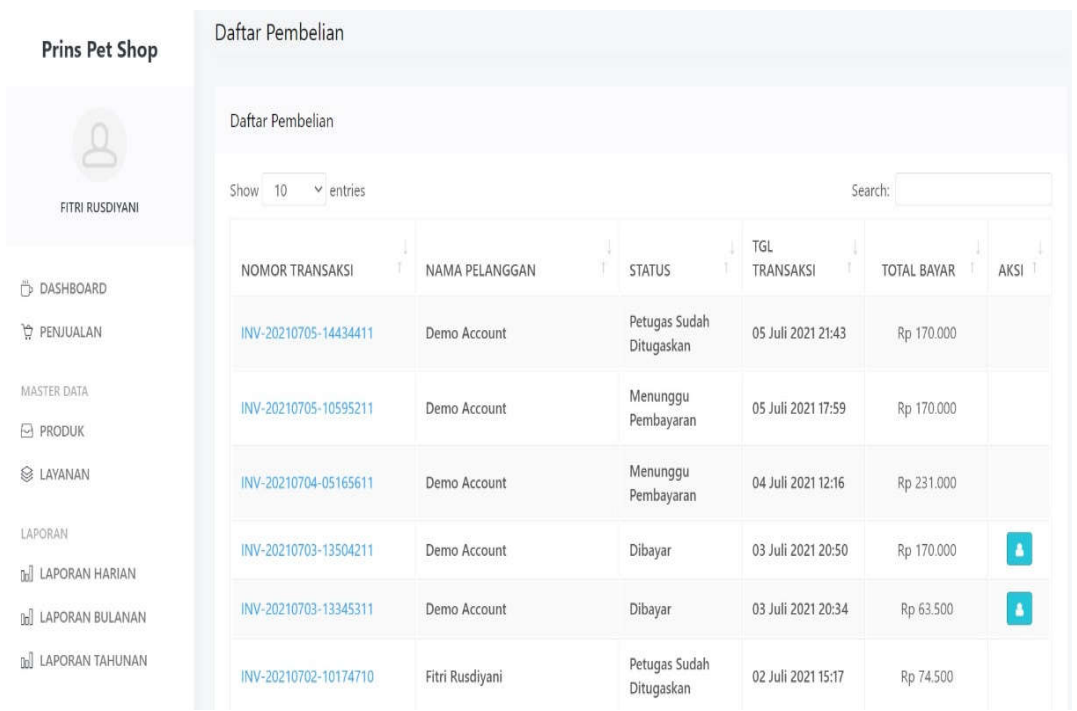

Gambar 4. Halaman Penjualan

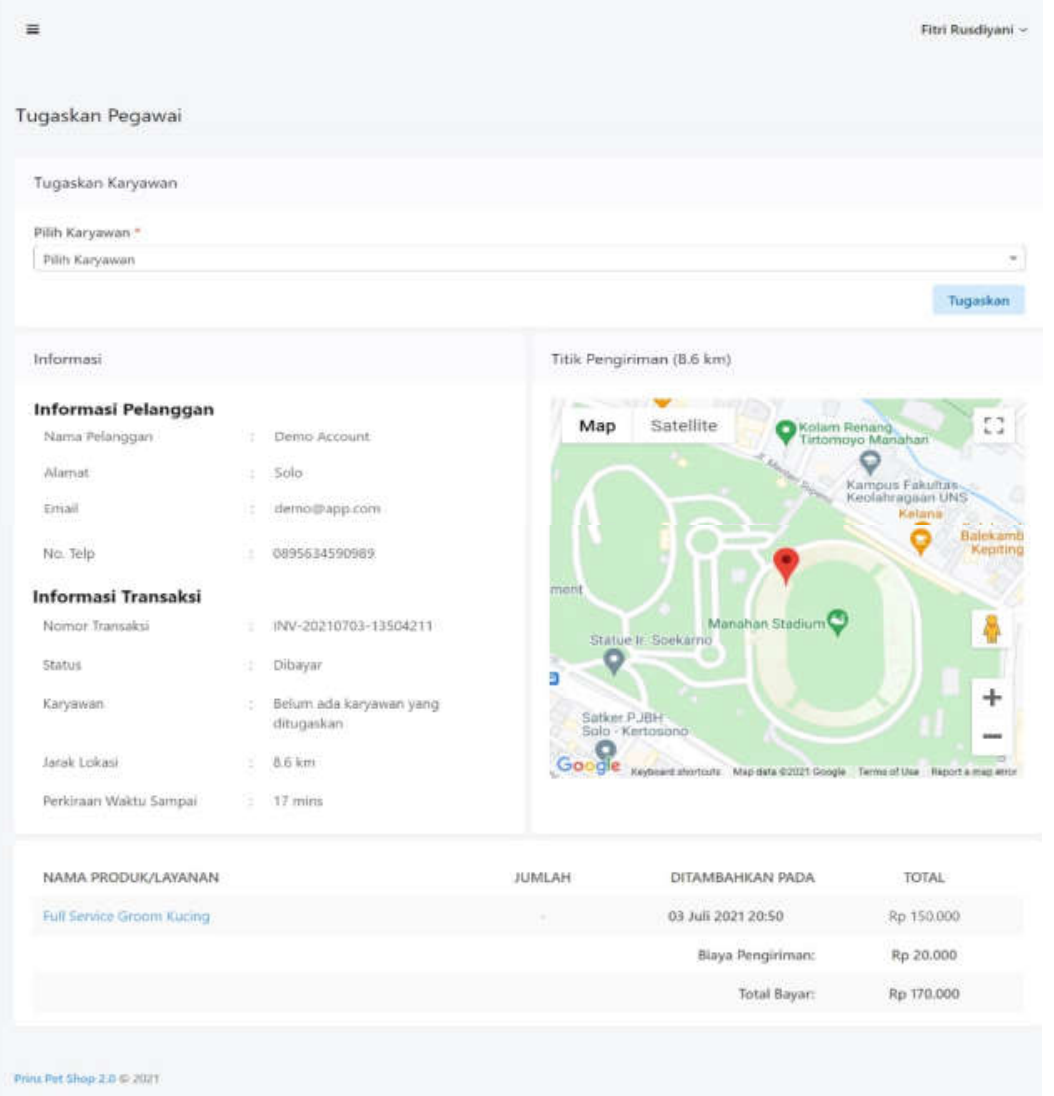

Gambar 5. Halaman Penugasan Sales 


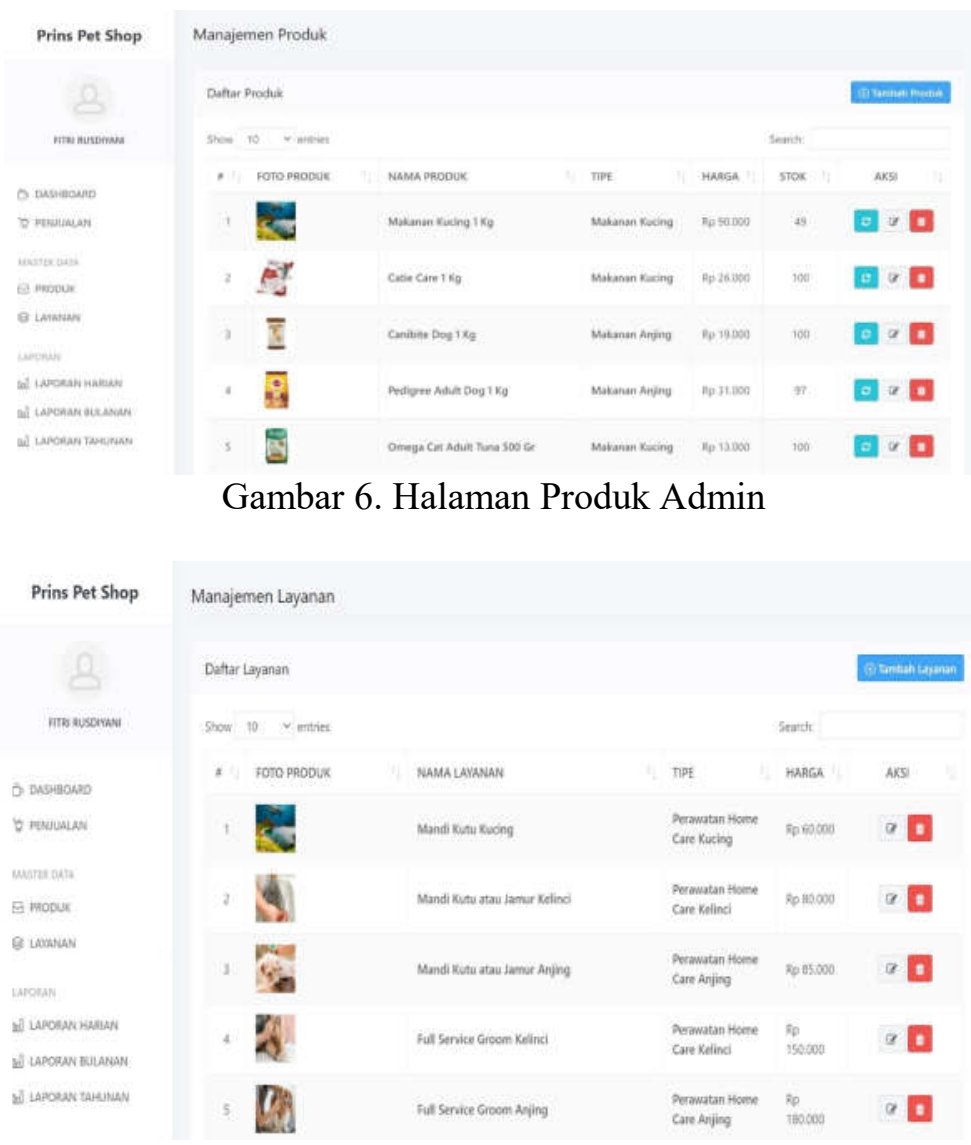

Gambar 7. Halaman Layanan Perawatan Admin

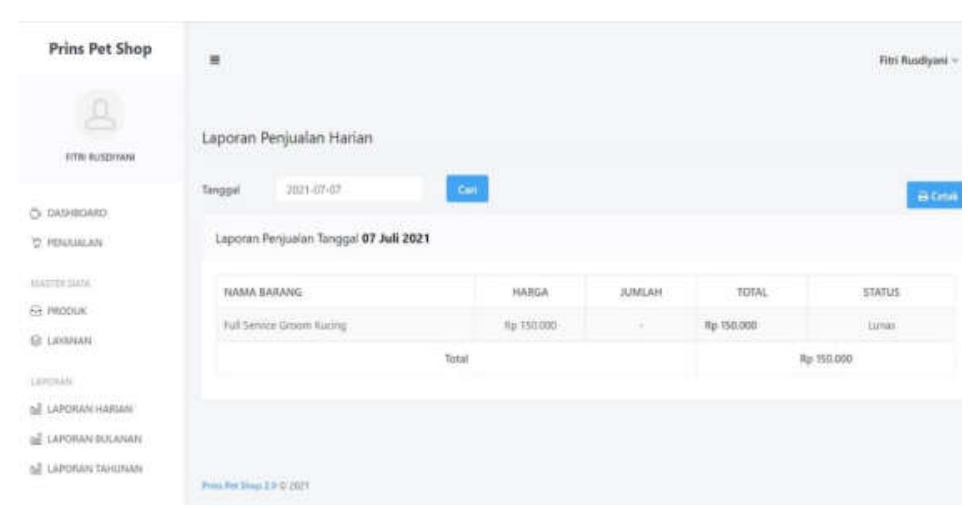

Gambar 8. Halaman Laporan Admin 


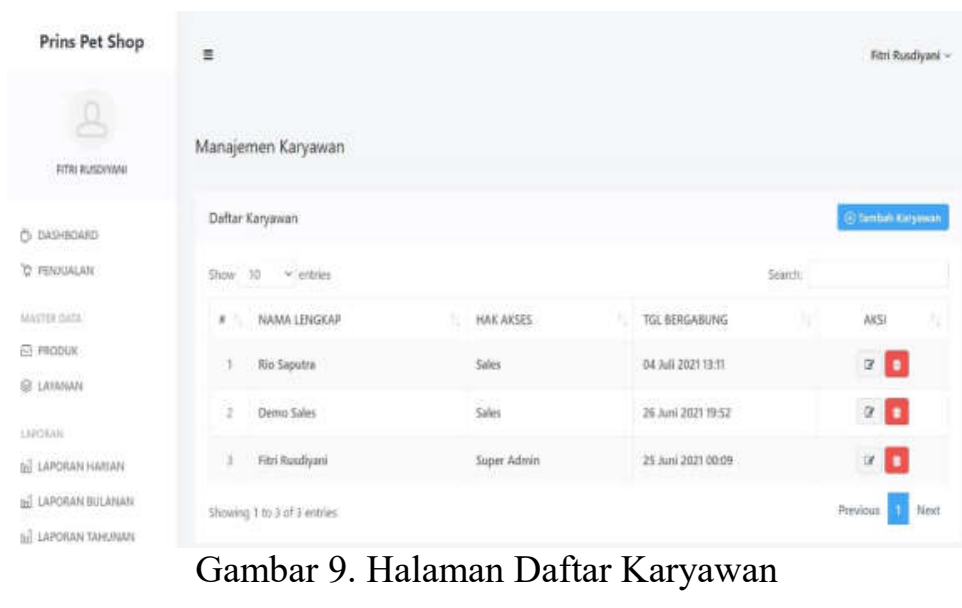

\subsection{Pemeliharaan Sistem}

Tahap pemeliharaan dilakukan setelah tahap implementasi. Sistem baru yang berjalan digunakan sesuai dengan keperluan perusahaan. Selama masa hidupnya, sistem secara periodik akan ditinjau. Perubahan akan dilakukan jika muncul masalah atau jika ternyata ada kebutuhan baru. Selanjutnya, organisasi akan menggunakan sistem yang telah diperbaiki tersebut. Pemeliharaan sistem meliputi:

a. System Back-Up

Membuat salinan/copy untuk data-data penting yang ada pada komputer admin maupun server kedalam backup storage.

b. System Optimization

Melakukan Defragmentasi data dan membuang sampah-sampah yang ada pada komputer, serta memperbaiki kesalahan setting sehingga komputer dapat berjalan normal.

c. System Rebuild

Membangun dan menata ulang kembali sistem yang rusak oleh faktor yang tidak disengaja, agar dapat bekerja normal kembali.

d. System Upgrade

Menambah fungsi, memperbaharui sistem yang ada sesuai dengan kebutuhan admin, serta melakukan testing stabilitas untuk hardware dan software.

e. Training dan Pelatihan

Memberikan pengarahan dan konsultasi kepada admin agar dapat mengoperasikan aplikasi sesuai dengan prosedur pengoperasian yang baik dan benar.

f. Update Anti Virus dan Pembersihan Virus

Melakukan update definition file anti virus sehingga anti virus yang ada dapat memproteksi komputer dari serangan virus dan juga melakukan scaning virus serta membersihkan komputer dari virus.

g. System Security

Pemasangan firewall dan sistem authentifikasi untuk pengamanan sistem dan data penting sistem informasi penjualan bibit ayam atau obat-obatan dari orang luar yang tidak berkepentingan.

Langkah-langkah pemeliharaan sistem terdiri dari:

a. Penggunaan Sistem

Menggunakan sistem yang sesuai dengan fungsi tugasnya masing-masing untuk operasi rutin atau sehari-hari 
b. Audit Sistem

Melakukan penggunaan dan penelitian formal untuk menentukan seberapa baik sistem baru dapat memenuhi kriteria kinerja. Hal semacam ini disebut penelaahan setelah penerapan dan dapat dilakukan oleh seorang auditor internal.

c. Penjagaan Sistem

Melakukan pemantauan untuk pemerikasaan rutin sehingga sistem tetap beroperasi dengan baik. Selain itu juga untuk menjaga kemutakhiran sistem jika sewaktu-waktu terjadi perubahan lingkungan sistem atau modifikasi rancangan software.

d. Perbaikan Sistem

Melakukan perbaikan jika dalam operasi terjadi kesalahan (bugs) dalam program atau kelemahan rancangan yang tidak terdeteksi saat tahap pengujian sistem.

e. Peningkatan Sistem

Yaitu melakukan modifikasi terhadap sistem ketika terdapat potensi peningkatan sistem setelah sistem berjalan beberapa waktu.

\section{KESIMPULAN}

Sesuai dengan hasil penelitian dan tujuan yang ingin dicapai dari pengembangan aplikasi pelayanan Prins Pet Shop berbasis android, maka dapat diambil kesimpulan bahwa dengan adanya aplikasi pelayanan Prins Pet Shop berbasis android mampu mempermudah pelanggan untuk melakukan pemesanan pelayanan kapanpun dan dimanapun tanpa harus datang langsung ke toko. Hasil perancangan aplikasi pelayanan Prins Pet Shop berbasis android terdiri dari flowchart, UML (Unified Modeling Language) yang terdiri dari Usecase Diagram, Activity Diagram, Sequence Diagram, Class Diagram dan Realitions Between Tables, sedangkan untuk metode pengembangan sistem menggunakan Metode Waterfall. Pengembangan sistem pada perancangan program ini menggunakan bahasa pemrograman pendukung Visual Studio Code versi 1.55.2 dan PHPMyAdmin sebagai pengolah database. Sistem ini bisa melakukan pengolahan data produk, layanan perawatan, form pemesanan, form transaksi dan laporan yang terdiri dari laporan penjualan harian, laporan penjualan bulanan dan laporan penjualan tahunan.

\section{SARAN}

Alat Saran yang penulis ajukan demi pengembangan aplikasi pelayanan Prins Pet Shop berbasis android di masa mendatang antara lain menambahkan kolom note atau catatan agar pelanggan dapat menuliskan catatan penting yang ingin disampaikan kepada pihak karyawan. Menambahkan kolom ulasan pelanggan setelah melakukan pemesanan pelayanan agar pelanggan dapat menyampaikan kritik dan saran. Pada pengembangan aplikasi pelayanan Prins Pet Shop berbasis android selanjutnya, diharapkan sistem dapat ditingkatkan dengan menambah fitur keamanan seperti account verification.

\section{DAFTAR PUSTAKA}

[1] Anhar. (2010). PHP \& MySQL Secara Otodidak. Agromedia Pustaka.

[2] Barakbah, A. R. (2013). Logika dan Algoritma. In PENS. Politeknik Elektronika Negeri Surabaya.

[3] Bootupacademyai. (2019). CSS (Cascading Style Sheets). 25 April. https://bootup.ai/blog/css-cascading-style-sheets-adalah-pengertian-belajar-desain-web/

[4] Deitel. (2012). C How to Program (7th ed.). Pearson Education, Inc.

[5] Ellislab. (2015). CodeIgniter. http://ellislab.com/codeigniter

[6] Kawistara, P. H. dan J. K. (2017). Pemrograman WEB Edisi Revisi. Informatika.

[7] Kroenke, D. M. (2005). Database Processing Jilid 1 (9th ed.). Erlangga.

[8] Lardinois, F. (2015). Google announces the first preview of Android Studio 3.0, puts emphasis on speed and smarts. https://techcrunch.com/2017/05/17/google-announces- 
the-first-preview-of-android-studio-3-\%0A0-puts-emphasis-on-speed-and-smarts/

[9] Linux, R. (2020). Seputar Visual Code: Fitur dan Fungsi. 08 Januari. https://www.rumahlinux.site/2020/01/seputar-visual-code-fitur-dan-fungsi.html

[10] Madcoms. (2016). Sukses Membangun Toko Online dengan PHP \& MySQL. Andi Offset.

[11] Nazir, M. (2013). Metode Penelitian. In Metode Penelitian. Ghalia Indonesia.

[12] Sugiyono. (2013). Metode Penelitian Kualitatif, Kuantitatif dan $R \& D$ (Cetakan ke). Alfabeta. 